\title{
Dr William Kerr "Bill" Collins, Recipient of the 2010 Tobacco Science Research Conference Lifetime Achievement Award
}

Laudatio to the award given by

J. Michael Moore

University of Georgia, Colleges of Agricultural and Environmental Sciences \& Familiy and Consumer Sciences, 2360 Rainwater Road, Tifton, GA 31793, USA

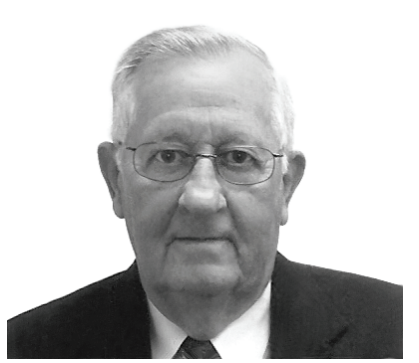

It is my distinct pleasure to make this presentation of the T S R C Lifetime Achievement Award to Dr Bill Collins from NC State University. Bill is well known in academic and industry circles for his contributions to Tobacco Science. Some have suggested that Bill Collins is the single person most identified with flue-cured tobacco at NC State and probably world-wide.

He has provided leadership of university efforts on behalf of the US flue-cured tobacco industry for more than 40 years. From conducting field research, to guiding leadership development programs, to advising county agents in their degree programs, to coordinating the tobacco programs of North Carolina State University, Dr Collins has had a lifetime of contributions which have benefitted tobacco producers, their county extension agents, university research and extension programs, and tobacco purchasing and manufacturing companies.

Dr Collins has been in the forefront of conducting field research on the production of flue-cured tobacco. He published the results in journals, university bulletins and popular press articles for use in educating tobacco farmers. Dr Collins lead the early efforts to develop chemicals for weed control and sucker control in commercial tobacco production greatly reducing the number of man hours required to produce quality tobacco.

As a result of his leadership dozens of memos on various recommended production practices were combined into one annually updated bulletin with input from extension specialists in all departments to provide tobacco growers with a handy source of "Tobacco Information".

This production guide approach has been adopted by most other tobacco state universities in the U.S. as the preferable means for presenting growers with current information on production practices and chemical use recommendations. Later, Dr Collins and Mr S.N. Hawks compiled much of this information into the premier book on Production of Flue-Cured Tobacco. This has been updated with later editions and translated into five languages with widespread use as a resource manual in all the major tobacco producing countries in the world.

Dr Collins is responsible for building much of the human capital which now leads the flue-cured tobacco industry. He led the development of relationships between the universities and the tobacco manufacturing industry to support further education of dozens of county extension agents to receive their masters degrees while working in tobacco counties.

In fact, Dr Collins trained three tobacco state extension specialists, Ben Kittrell (Clemson) and David Smith (NC State); and J. Michael Moore (Univ. of Georgia). The number of international visiting scholars with whom he cooperated are too numerous to count.

Dr Collins was largely responsible for organizing leadership development programs which have taught farmers and their spouses how to speak for agriculture through eight Leadership Development programs.

Many of these leaders now serve on committees and boards for tobacco as well as for many other commodities. Many now represent their neighbors and indeed the citizens of the state in elected office. The current President of the North Carolina Farm Bureau and the current Chairman of the NC 
State Board of Trustees are graduates of these programs. Dr Collins has developed an extensive network of acquaintances and friends throughout the tobacco industry and has an unrivaled ability to put together persons with ideas with others who have the abilities or capital to evaluate and develop innovative practices. In some cases the results have helped to revolutionize the tobacco industry.

The same has been true for his involvement with tobacco related activities like the Tobacco Literature Service and Tobacco Science when it was the efforts of Dr Bill Collins that convinced those with funds to support the continuation of these endeavors for the good of the tobacco industry. Hard economic times have now taken their toll on the Tobacco Literature Service, but Tobacco Science continues on firm ground and is one of the last places for tobacco scientists to publish their work in a peer-reviewed journal. Dr Bill Collins has served as a mentor to literally dozens of county agents, graduate students, industry representatives and visitors from around the world. Whether in the U.S. or in many of the tobacco producing countries, tobacco persons know the name of Bill Collins and have benefitted from his lifetime of work in and for the tobacco industry. It is for his lifetime of support and contributions to the tobacco industry and Tobacco Science that Dr Bill Collins is our recipient of this award.

\section{BIOGRAPHY OF DR COLLINS}

Collins was born on a flue-cured tobacco farm near Henderson, North Carolina where he graduated from Aycock High School after which he graduated in a posthigh school program from Randolph Macon Academy, Front Royal, Virginia. He received B.S. and M.S. degrees from North Carolina State University and worked four years in the Tobacco Variety Evaluation Program after serving two years as an officer in the U. S. army. His M. S. thesis formed the basis for the Minimum Standards Variety Release Program which has been in place since 1963. He received a Ph.D. in Crop Breeding from Iowa State University while in the corn Breeding Program. He worked three years as an agronomist for R. J. Reynolds Tobacco Company and became a faculty member at North Carolina State University (NCSU) in 1966 for the remainder of his professional career. He was a tobacco extension specialist for 20 years and taught a tobacco production course to more than 1000 students during this period.

Collins was a pioneer in the use of replicated on-farm tests to develop and bring about the adoption of tobacco sucker control chemicals (particularly alcohols), herbicides, fertilizers, and management practices as published in Tobacco Science. He was an expert witness in about 15 liability cases involving tobacco pesticides and fertilizers. He was associate head and/or Acting Head of the Crop Science Department in the College of Agriculture and Life
Sciences for 8 years. In 1994 he became the Coordinator of Tobacco Programs in the North Carolina Agricultural Research Service for 13 years when he regularly attended TSRC meetings and was a consistent supporter of the Tobacco Science publication and Tobacco Literature Service at NCSU.

He was the director or co-director of eight agricultural twoyear leadership programs, consisting of 50 days of training that helped develop many leaders in the tobacco industry, particularly the agricultural sector. He had a strong interest in young farmers and in 1978 helped establish a 4-day Short Course for Young Tobacco Farmers at NC State University with about 1200 attendees during the last 30 years.

He visited the tobacco production areas of 44 countries and understands the implications of international agricultural competition. In 1997 he became general manager of Turner Family Tobacco Farms in Warren County, North Carolina. Collins is the co-author of a book Principles of Flue-Cured Tobacco Production, published in five languages.

Membership in Professional Societies - NC Soil Science Society, President, 1970; Pesticide Association of NC; American Society of Agronomy and Crop Science Society of America; the Plant Food Association of NC.

Membership in Honorary Academic Societies at NC State University - Alpha Zeta as sophomore; President, Blue Key and Senior Class, Golden Chain; Sigma Xi, Gamma Sigma Delta (President, 1979); President, NC Alpha Zeta Alumni Association, 1977 and 1999.

Honors and Awards Received - Most Outstanding Senior Award in Agronomy, NCSU, 1954; Gamma Sigma Delta Recognition for Meritorious Service Award, 1975; Philip Morris Professor (one of three named Extension Specialists on campus), 1978; Outstanding Extension Service Award, NCSU, 1978-79); Superior Leadership Award, NC Agricultural Extension Service, 1979; Agronomy Club Outstanding Instructor Award in 1978; Agronomic Extension Award from the American Society of Agronomy, 1981.

$\mathrm{He}$ is married to the former Ann Kittrell Turner and has three children: Julie, Lori, and Kerr; and has three grandchildren: Alexa, Will and Robert.

\section{Corresponding author:}

\section{J. Michael Moore}

Professor \& Extension Agronomist - Tobacco

University of Georgia

Colleges of Agricultural and Environmental Sciences \&

Familiy and Consumer Sciences

2360 Rainwater Road

Tifton, GA 31793

E-mail: jmmoore@uga.edu 